\title{
Flowering Mechanism as a Major Factor for Adaptation of Oats for Forage Management in Middle Latitudes
}

ISSN: 2637-7659

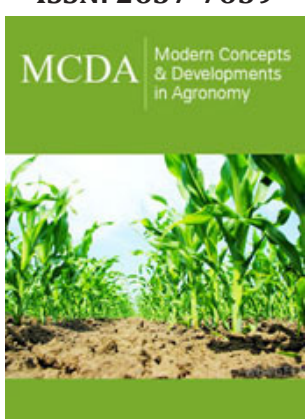

*Corresponding author: Alejandro La Manna, National Agricultural Research Institute (INIA) of Uruguay, Ruta 50km, 11 Colonia, Uruguay

Submission: 眥 September 06, 2021

Published: 海 September 17, 2021

Volume 9 - Issue 4

How to cite this article: Federico Condón Rodrigo Zarza, Alejandro La Manna. Flowering Mechanism as a Major Factor for Adaptation of Oats for Forage Management in Middle Latitudes. Mod Concep Dev Agrono. 9(4). MCDA. 000716. 2021. DOI: 10.31031/MCDA.2021.09.000716

Copyright@ Alejandro La Manna. This article is distributed under the terms of the Creative Commons Attribution 4.0 International License, which permits unrestricted use and redistribution provided that the original author and source are credited.

\author{
Federico Condón, Rodrigo Zarza and Alejandro La Manna* \\ National Agricultural Research Institute (INIA) of Uruguay, Uruguay
}

\begin{abstract}
Winter annual forage crops like oats, wheat, triticale and even barley can be planted at the end of summer (mid-February) to supply fresh forage in a situation of low dry matter availability. This means sowing an annual cereal out of its natural planting window, which normally is in cooler weather condition (March through June in Southern Hemisphere) and exposing the plants to a high temperature environment that can lead to a quick flowering induction of tillers. Therefore, we conclude that the selection of adapted forage genotypes by evaluation of regrowth, tillering and forage production should be complemented by a phenological characterization that should lead to a selection of better adapted forage genotypes.
\end{abstract}

Keywords: Oat; Forage; Flowering genetics; Phenology

\section{Introduction}

Animal production in Uruguay, both for dairy and beef [1,2] relies mainly on direct forage grazing. Forage production is achieved with natural pastures or cultivated non-irrigated perennial pastures. As a complementary forage source, summer annual crops (corn, sorghum and foxtail millet (Setaria italica)) are used as a reserve for low forage periods. Late-summer and early-fall is a time of the year in which summer forage crops have finished their cycle and spring and fall planted perennial pastures are still in their establishment phase, therefore not yet productive. This transition can cause a reduction in the forage production area up to a $33 \%$ [3], leading to a limited forage allowance. Dry years may also lead to poor implantation of summer forage crops and cause a forage crisis, driving farmers to an early use of forage reserves, which does not solve the problem, but moves it forward in time. This shortage is not exclusive to Uruguay; it has been reported in Wisconsin [4], Kansas [5], Oklahoma [6], Arkansas [7], New York [8], Canada [9,10], Rio Grande do Sul, Brazil [11,12] Parana, Brazil [13], Spain [14,15] and also in Korea [16]. The use of annual cool-season forages (oat, wheat or ryegrass) extends the grazing season into the winter and provides good-quality forage [17]. Traditionally, the yellow oat cultivar 'La Estanzuela 1095a' [18] is planted late fall (late March and early April) in Uruguay for winter forage production. Forage harvest starts by the end of April- beginning of May, when the growth rate is already reduced by low temperatures. As a response to this situation, farmers began planting oats and other annual grasses by the end of summer (late January and mid-February) in an environment characterized by temperatures higher than optimum for the germination of some species, drought risk due to high atmospheric water demand and a long daylength (13hs 20 min for February $15^{\text {th }}$ in Uruguay, $34^{\circ} 20^{\prime} 13.29^{\prime \prime} \mathrm{S}, 57^{\circ} 41^{\prime} 12.87^{\prime \prime} \mathrm{W}$ ) compared to winter ( $9 \mathrm{hs} 48 \mathrm{~min}$ for June $15^{\text {th }}$ ). Pests, like soil-born insects and aphids [18] and diseases like leaf rust, are common under this environmental condition, posing extra challenges for a good crop achievement. 
Planting date has been identified as the main factor for seasonal forage yields in Texas [5,19] and Oklahoma [20] for winter wheat, oats, and ryegrass. Early planting dates favored higher yields in fall season not affecting winter and spring forage yields. Ryegrass in an intermediate planting date produced significantly higher yields in fall and spring seasons but did not affect winter production. Feed quality has been characterized as declining over time with increases in maturity, with an advantage for those cultivars with delayed maturity in early planting dates [21-23]. This effect could be controlled by early initial grazing dates [24].

Late-summer planted grasses, in Wisconsin, showed a yield advantage $[5,25]$ an effect explained for some cultivars by an early stem elongation. Forage delivery moment is also affected by planting date; in Oklahoma, a rye crop delivered forage earlier; but triticale's, wheats and oats showed a production curve that peaked later (after 100 to 130 days of growth) [6]. Similar results are reported for the Rio Grande do Sul state (Brazil) but including ryegrass that achieved its highest production rate in spring [26].

Therefore, it is expected that the interaction genotype (both species and cultivar) by environment (year and date of sowing) influence the forage both for the time of delivery and for the seasonal yield. For this reason, it is important to evaluate these effects during autumn and winter, to establish the optimal cultivar selection criteria and determine the potential capacity of the different options.

Cereal flowering mechanisms exist to determine when to switch from the vegetative to the reproductive stage using genes and mechanisms that monitor environmental variables. Head timing and photoperiod sensitivity define the potential adaptation of plants to different environments and cropping systems based on environmental variables such as day length (photoperiod) and temperature [27]. Temperate species also respond to variations in both photoperiod and exposure to low temperatures (vernalization). This mechanism makes fall planted crops flower during spring, therefore avoiding flowering during winter [28]. Short day conditions (+8 light hours) delay flower induction, which is enhanced by long day environments (+16 light hours). In midrange latitudes, under fall planting conditions, spring cultivars are sensitive to low temperatures, do not have photoperiod sensitivity, and vernalization is not required to flower in the right moment [29].

\section{Discussion}

The transition from Summer to Fall and Winter in middle range latitudes represents a time period in which temperature gradually decreases as well as daylength becoming factors that gradually are limiting for plant growth and development.

The changes in planting date reported in our previous review, can be interpreted as changes in the environment temperature and daylength that the crop must face in its implantation and initial development period. If water stress is not present, and temperatures allow the crop implantation, then annual forage crops must face and environment that presents high temperatures and a daylength period in reduction, before entering in a situation in which winter low temperatures and short daylength become limiting factors for plant development.

Under this scenario, an annual crop like oat can be benefited from and early planting date by relatively high temperatures that allow a good initial growth and establishment of the crop but should also remain vegetative. Theoretical relationship between planting date and expected flowering date based on observational data is presented in Figure 1.

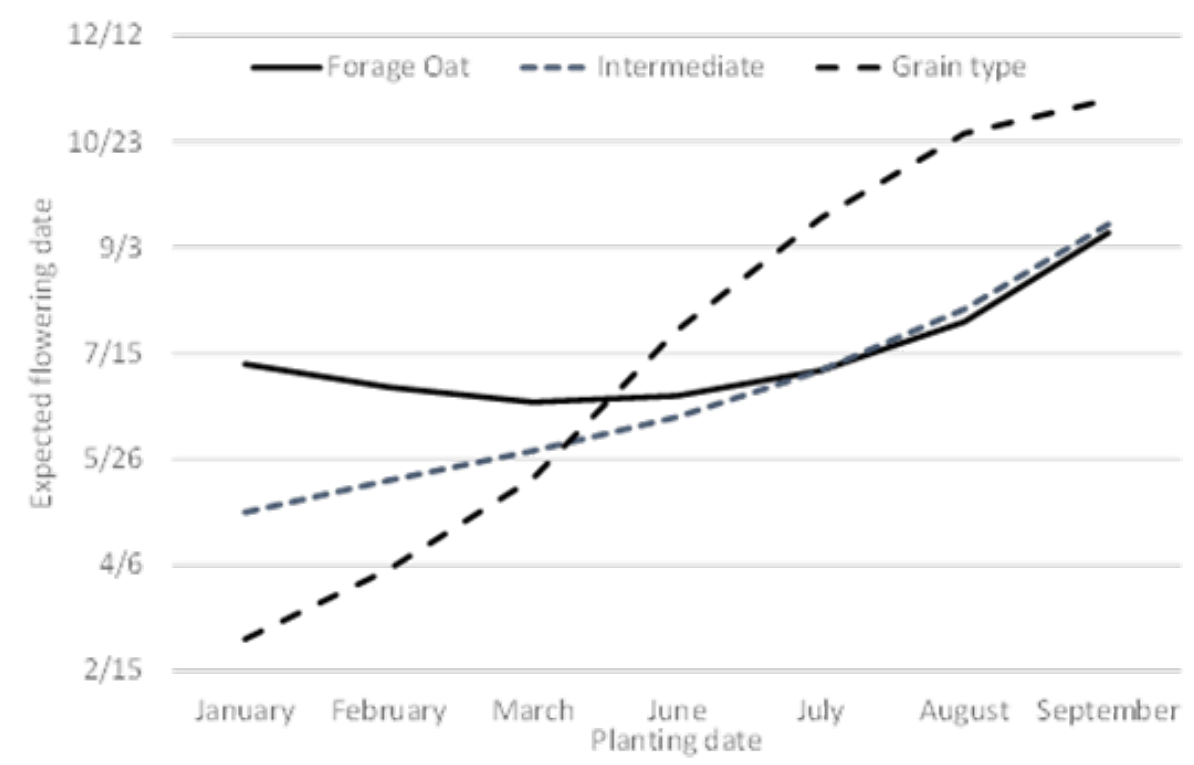

Figure 1: Planting date and expected flowering date for a) forage oat-cultivar 'Estanzuela 1095a'; b) intermediate forage oat and c) grain type oat. Observations at the Forage Breeding Program, INIA La Estanzuela, Colonia Uruguay (Condon, F. com pers). 
For a forage oat, that is expected to be grazed, and regrowth afterward to be grazed again, early floral induction remains a limiting factor. Induced tillers won't regrowth, and even new tillers will regrowth already induced.

This means that fall-planted annual oat forage crops should have different flowering genetics when compared with grain crops that must ensure the plants stay vegetative even when planted in summer or fall, by combining vernalization requirements, photoperiod sensitivity, or both factors. This effect was clearly reported by [30] at La Estanzuela in 2018, as presented in Table 1.

Table 1: Average dry matter $\left(\mathrm{kg} \mathrm{ha}^{-1}\right)$ production of 3 oat cultivars under three different managements, La Estanzuela, Colonia, Uruguay. Planting date: February $14^{\text {th }}, 2018$.

\begin{tabular}{|c|c|c|c|c|c|c|c|c|}
\hline \multicolumn{9}{|c|}{ Grazing Date Dry Matter Availability (kg ha-1) } \\
\hline Cultivar & Management & 17-Apr & 21-May & $\mathbf{\Omega}$ & 12-Jul & 29-Aug & Sept 25 & 16-0ct \\
\hline \multirow{3}{*}{$\begin{array}{l}\text { Experimental } \\
\text { gran oat (1) }\end{array}$} & Grazing & 1493 & 1991 & $a b$ & - & - & - & - \\
\hline & Grazing+closure & 1746 & 2234 & $\mathrm{a}$ & - & - & - & - \\
\hline & Accumulation & 1784 & 1138 & $\mathrm{~d}$ & - & - & - & - \\
\hline \multirow{3}{*}{ LE1095a (2) } & Grazing & 1297 & 1553 & bcd & 2120 & 2944 & & \\
\hline & Grazing+closure & 1445 & 1730 & $\mathrm{bc}$ & 2429 & 3340 & 5194 & 8557 \\
\hline & Accumulation & 1253 & 1654 & $\mathrm{bc}$ & 3484 & 4750 & 5846 & \\
\hline \multirow{3}{*}{$\begin{array}{l}\text { INIA Columba } \\
\text { (3) }\end{array}$} & Grazing & 745 & 1143 & d & 1983 & 2996 & - & - \\
\hline & Grazing+closure & 888 & 1374 & $\mathrm{~cd}$ & 2080 & 2628 & 5437 & 8430 \\
\hline & Accumulation & 967 & 1343 & $\mathrm{~cd}$ & 3742 & 5403 & - & - \\
\hline
\end{tabular}

(1) Grain type cultivar; (2) Forage type cultivar; (3) intermediate cultivar. $\Omega$ Means with the same letter indicate that values corresponding to the same grazing date are not statistically different a $p<0,05$. Management: Grazing: grazed by cattle at the indicated dates. Grazing+closure: grazed at indicated dates until July 12th; then closed for accumulation; Accumulation: not grazed. Adapted of [30].

The mini review presented indicates that for an Oat grain cultivar, that does not have neither vernalization requirements nor photoperiod sensitivity as Experimental line 1 (grain type, in table 1) cannot be considered as useful for forage production, since planted in mid-February and flowered early in May, yielding only two grazing opportunities. On the other hand, forage cultivar Estanzuela 1095 a and Intermediate Cultivar INIA Columba yielded four grazing opportunities and the chance of closing the plot for forage accumulation for hay production, which translated in a much higher total dry-matter production per hectare. Similar situation was observed in Uruguay by [31], in this case for different species of annual cereals that were tested as forage crops, but in general the same effect was observed, as short cycle cultivars offered a forage early, but reduced later production, and those cultivars without vernalization requirements did not adapt to early planting dates (end of summer early fall). These elements indicate that a phenological characterization of the breeding lines is necessary with a wide range of sowing dates or different latitudes to determine the flowering mechanisms of different genotypes or the use of tools such as marker-assisted selection [32]. The development of this type of management then makes possible at the field level the existence of more flexible materials in their forage contribution and in the face of environmental conditions.

\section{References}

1. NC-27 (2012) Evolution environmental in areas affected by pollution, caused by santa lucia mineral deposit, Pinar el Rio. Especificaciones. ININ/ Oficina Nacional de Normalización. La Habana, Cuba, p. 11.
2. NC-855 (2011) Utilización de las aguas residuales de la industria azucarera y de derivados en el fertirriego de la caña de azúcar. ININ/ Oficina Nacional de Normalización, La Habana, Cuba, p. 13.

3. NC-1095 (2015) Microbiología del agua. Detección y enumeración de coliforms, Técnicas del número más probable (NMP). Oficina Nacional de Normalización (NC), La Habana, Cuba, p. 23.

4. Brito A, Delgado O, Villarreal M (2019) Evaluación de los residuales generados en el sistema de tratamiento del integral porcino \# 1. Reporte de investigación. Cienfuegos, Cuba, p. 9.

5. Francesena Y (2016) Impacto ambiental provocado por efluentes de instalaciones de biogás de pequeña y mediana escala en las provincias de la región central de Cuba. Trabajo de diploma (en opción al título de Ingeniero Agrícola). UCLV, Cuba, p. 51.

6. Fabregat J (2019) Treatment and use of effluents from pig biodigesters as organic fertilizers. Trabajo de diploma (en opción al título de Ingeniero Agrícola). UCLV, Cuba, p. 64.

7. Llama DA (2019) Evaluation of the effect of the slow sand filter for the treatment of effluents from oxidation lagoons in the UCLV, Central University of Las Villas UCLV, Diploma Work (in option to the title of Hydraulic Engineer), Santa Clara, Villa Clara, Cuba, p. 54.

8. Sánchez J (2020) Use of effluents from oxidation lagoons of the CAI "Carlos Baliño" as organic fertilizers, Central University of Las Villas UCLV Faculty of Agricultural Sciences, Diploma work (in option to the title of Agricultural Engineer), Santa Clara, Villa Clara, Cuba, p. 92.

9. Villareal VM (2017) Evaluation of local materials in the manufacture of filters for drinking water treatment. Trabajo de diploma (en opción al título de Ingeniero Hidráulico). Universidad Central "Marta Abreu" de Las Villas, Cuba, p. 57.

10. Ramírez E (2021) Análisis del efluente del CAI "George Washington" para su posible uso como abono orgánico. Trabajo de Diploma (en opción al título de Ing. Agrícola), UCLV, Cuba, p. 109.

For possible submissions Click below: 